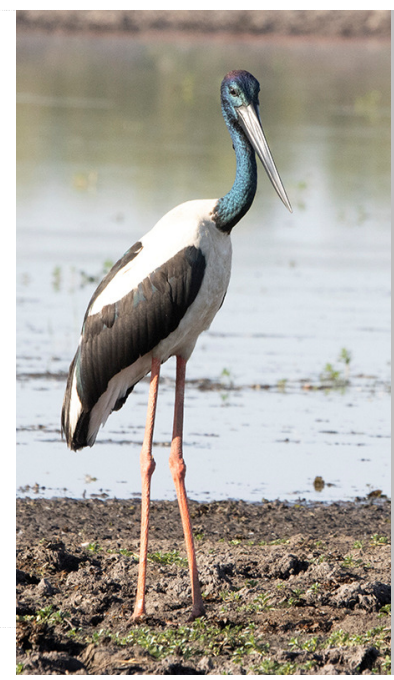

\title{
SPEAKING A COMMON LANGUAGE ON WHAT SHOULD COUNT FOR PROTECTING 30 PER CENT BY 2030?
}

\author{
Stephen Woodley ${ }^{1^{*}}$, Madhu Rao ${ }^{1}$, Kathy MacKinnon ${ }^{1}$, Trevor \\ Sand with ${ }^{2}$ and Nigel Dudley ${ }^{1}$ \\ * Corresponding author: Woodleysj@gmail.com
}

${ }^{1}$ World Commission on Protected Areas, International Union for Conservation of Nature ${ }^{2}$ Centre for Conservation Action, International Union for Conservation of Nature

\section{ABSTRACT}

Increases in area-based conservation are essential to halt biodiversity loss and respond to climate change. Parties to the Convention on Biological Diversity are poised to adopt a target of protecting at least 30 per cent of the Earth's lands, seas and freshwater by 2030. This is in the draft Global Biodiversity Framework and supported by over 70 countries who have joined the High Ambition Coalition. The IUCN World Commission on Protected Areas, in partnership with UNEP - World Conservation Monitoring Centre, National Geographic, the Wildlife Conservation Society and Birdlife International has published guidance entitled 'Conserving at least $30 \%$ of the planet by 2030: What should count?'. This guidance calls for a focus on quality as an essential part of large area-based conservation targets. Quality includes many elements, including a focus on establishing protected and conserved areas in areas important for biodiversity, how they are designed and ecologically connected, and ensuring management effectiveness and governance equity. But protected and conserved areas must be realised in full partnership with Indigenous and local communities. The 30 per cent minimum target provides a significant opportunity to strengthen security of tenure, land and use rights especially for Indigenous Peoples and support to IPLC-led conservation efforts. Moving to protect at least 30 per cent of the Earth by 2030 is a grand challenge in which we need to speak a common language.

Key words: protected areas; conserved areas; ecological connectivity; Convention on Biological Diversity; conservation equity

As Parties prepare for $\mathrm{COP} 15$ of the Convention on Biological Diversity, there is major global momentum towards establishing a more ambitious target of protecting at least 30 per cent of lands, oceans and freshwater by 2030. This milestone towards living in harmony with nature by 2050 is written into the first draft of the Global Biodiversity Framework under the Convention on Biological Diversity (CBD), building on Aichi Target 11. Scientific support (Woodley et al., 2019) for this level of ambition is clear and that 30 per cent is an absolute minimum target. The IUCN World Conservation Congress in Marseille, France adopted a resolution calling for IUCN "to support, at a minimum, a target of effectively and equitably protecting and conserving at least $30 \%$ of terrestrial areas and of inland waters and of coastal and marine areas respectively...". This became part of the Marseille Manifesto, which "implored governments to set ambitious protected area and other effective area-based conservation measure targets by calling for at least 30\% of the planet to be protected by 2030 ". The 'at least 30 per cent by 2030' target is now IUCN policy.
Over 70 countries have signed onto the High Ambition Coalition ${ }^{\mathrm{ii}}$, championing a global deal for nature and people, with the central goal of protecting at least 30 per cent of the world's land and ocean by 2030.

A focus on area-based conservation is justified, as the key driver of biodiversity loss is when wildlife habitat is either degraded, often through fragmentation, or destroyed by human activities. Climate change amplifies these pressures. Effective protected and conserved areas are an essential part of solving the global biodiversity crisis, while increasing and protecting carbon stocks in natural ecosystems helps to address the climate crisis.

Global Biodiversity Framework Draft 1 - Target 3. Ensure that at least $30 \%$ globally of land areas and of sea areas, especially areas of particular importance for biodiversity and its contributions to people, are conserved through effectively and equitably managed, ecologically representative and well-connected systems of protected areas and other effective area-based conservation measures, and integrated into the wider landscapes and seascapes. 


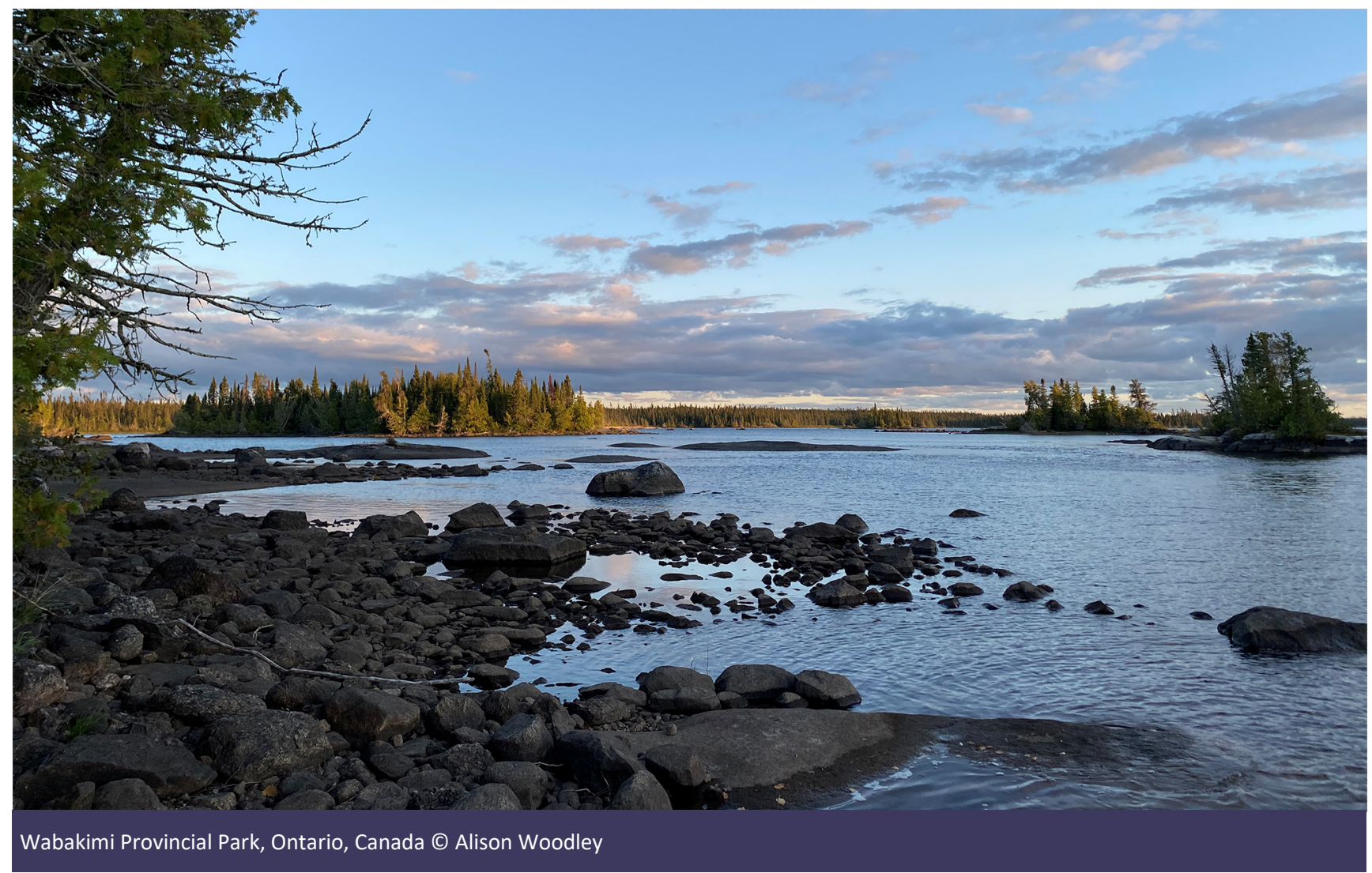

\section{WHAT CAN BE COUNTED TOWARDS THE 30 PER CENT TARGET?}

The 'at least 30 per cent' figure should include only protected areas and other effective area-based conservation measures (OECMs). Both these types of area-based conservation measures are defined under the CBD and both have extensive CBD and IUCN guidance. Protected and conserved areas represent a wide variety of approaches to ensuring specific biodiversity outcomes. Four governance types are recognised by the IUCN: 1) government; 2) shared, 3) private and 4) Indigenous Peoples and Local Communities. All governance types are important. IUCN's six protected area categories are approaches to management that can be used to meet a wide variety of goals and approaches. This matrix of options for the governance and management of protected and conserved areas is inclusive of the variety of approaches to governance undertaken by a broad constituency of authorities including Indigenous Peoples and local communities.

In implementing the area-based global target of protecting at least 3oper cent by 2030, the focus must be on quality, both for what is conserved and for how it is conserved. The protected and conserved areas that would constitute the 30 per cent of the planet must deliver positive outcomes for biodiversity. We know that biodiversity outcomes are a function of quality, meaning selecting areas that are important for biodiversity, and ensuring sound ecological design, equitable governance and effective management. Protected and conserved areas must also be socially just and sustainable, not only respecting rights and principles of justice, but engaging the whole of society in their governance and management.

The IUCN World Commission on Protected Areas, in partnership with UNEP - World Conservation Monitoring Centre, National Geographic, the Wildlife Conservation Society and Birdlife International has published guidance entitled 'Conserving at least 30\% of the planet by 2030: What should count?' (IUCN-World Commission on Protected Areas, 2021). This guidance, already available in four languages, consolidates and summarises existing IUCN guidance and decisions of the $\mathrm{CBD}$, to enable practitioners to speak a common language on what counts. Halting biodiversity loss is a global ambition, implemented according to national circumstances. However, implementation must follow a set of principles and standards.

First some context. We cannot simply protect 30 per cent of the planet and forget about the rest. The $30 \times 30$ 
target represents high quality, nature-first protection that forms the backbone of halting biodiversity loss. But to live in harmony with nature, we must think about 100 per cent of the planet. The other 70 per cent must focus on well-managed, biodiversity-friendly systems for agriculture, grazing, forestry, fishing, transportation and urban areas. We need a whole-Earth solution. We should not try and pack all our required conservation actions into the 30 per cent that is protected or conserved.

Protecting and conserving at least 30 per cent by 2030 must be addressed in the context of recognising the rights of Indigenous Peoples and Local Communities (IPLCs). It is well established that Indigenous and community-governed territories often effectively retain their biodiversity conservation values (Schuster et al., 2019). It is also clear that protecting at least 30 per cent of the Earth will not occur without the leadership, support and partnership of Indigenous Peoples, local communities, and other governing authorities.

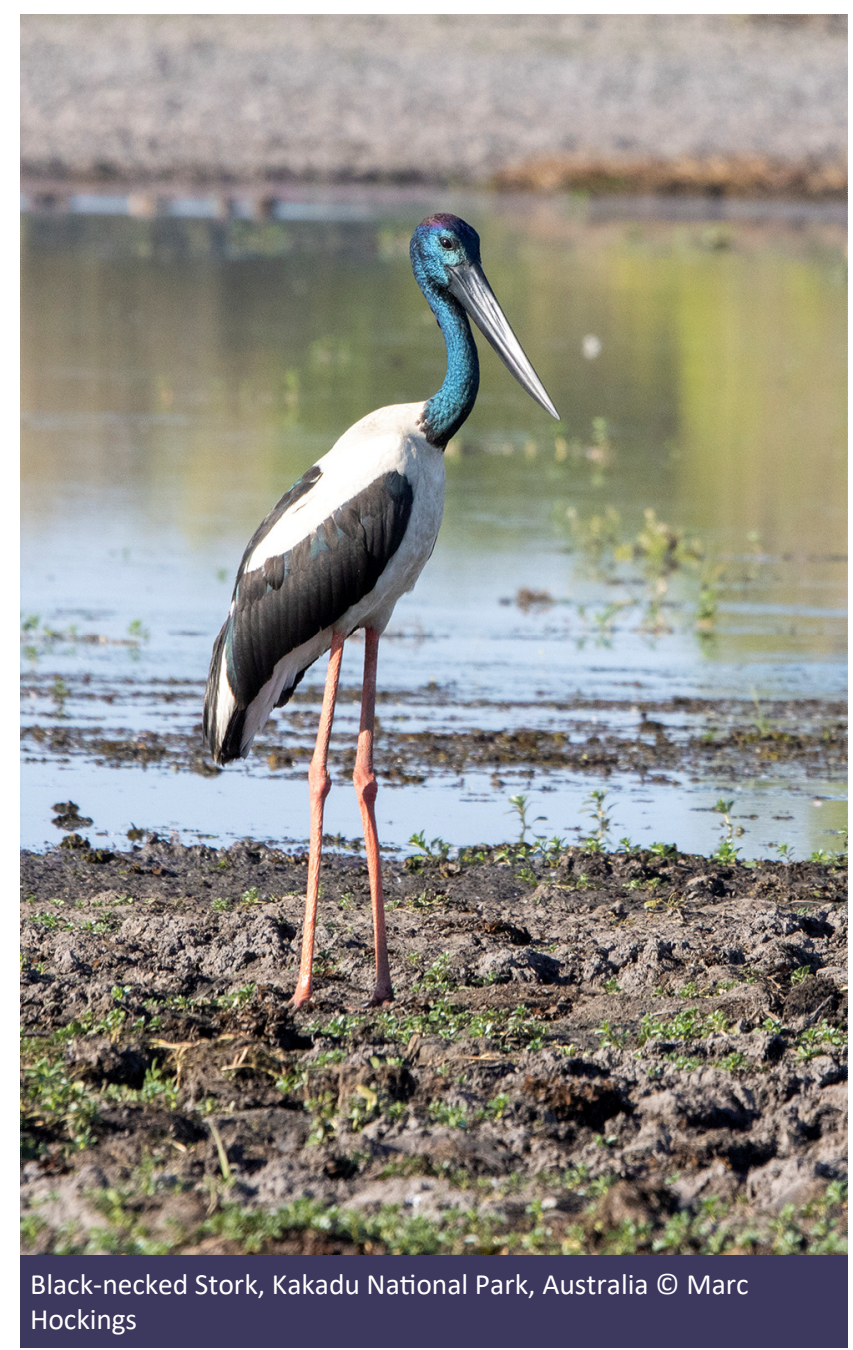

Protected and conserved areas can provide enormous benefits at the local level (Naidoo et al., 2019), but they must be recognised and managed with due regard for human rights (Tauli-Corpuz et al., 2020). This in turn means that there will be many more stakeholders and rightsholders involved in decisions about how, where and what to conserve. Traditional knowledge will be taken into account alongside those of conservation scientists. Conservation works best when it is equitable: based on full participation, shared and transparent decision-making, rights-based approaches, and fair benefit sharing. The 30 per cent minimum target provides a significant opportunity to strengthen security of tenure, land and use rights especially for Indigenous Peoples and support IPLC-led conservation efforts. Protecting at least 30 per cent is not a land or sea grab. It is an opportunity to recognise and support the rights of IPLCs.

\section{A FOCUS ON AREAS IMPORTANT FOR BIODIVERSITY}

Biodiversity is not distributed evenly across the globe. Effective conservation requires the identification and protection of areas that are especially important for biodiversity. Countries should focus on protecting and conserving Key Biodiversity Areas (KBAs), defined as "sites contributing significantly to the global persistence of biodiversity". IUCN has developed a Global Standard for the Identification of Key Biodiversity Areas (IUCN, 2016) for countries to use to identify KBAs. The Key Biodiversity Areas Partnership has identified over 16,000 sites globally and countries are called on to identify new sites against the criteria of the Standard. In addition to KBAs, other important sites include Ecologically or Biologically Significant Marine Areas, or EBSAs, Important Marine Mammal Areas, and equivalent national high-priority areas. All these areas can be managed as protected areas or OECMs, depending on the context.

\section{MOVING FROM CONSERVATION ISLANDS TO CONSERVATION NETWORKS}

It is clear that we need to move from protecting individual sites to protecting ecological networks. Important sites should be linked into effective ecological networks through systematic conservation planning to optimise biodiversity conservation. With increasing habitat loss and fragmentation, maintaining and conserving ecological connectivity is essential, especially in a world that is impacted by climate change. IUCN has published guidance on ecological corridors and networks (Hilty et al., 2020) and work is underway to report these to the Protected Planet (UNEP-WCMC, IUCN, 2021) database. 


\section{EFFECTIVE CONSERVATION}

Countries report, through the Protected Planet database, that they currently protect and conserve 16.7 per cent of land and 8 per cent of the global ocean. Unfortunately, many of those protected areas are not well managed or even managed at all, nor do all the areas reported as 'protected areas' meet the definitions of IUCN and the CBD. Conversely, some protected areas - particularly privately protected areas and ICCAs, are not included in government statistics. Many governments are under-investing in conservation, and protected areas are being logged and converted to agriculture rather than being well managed.

Common standards should be applied to both protected and conserved areas so that they are well- designed, well-governed and effectively managed in ways that lead to positive conservation outcomes. The IUCN Green List of Protected and Conserved Areas (Hockings et al., 2019) provides a global standard that applies to land, inland waters, and marine and coastal environments. The Green List criteria can be used to guide authorities and managers of all kinds in seeking to make their protected and conserved areas more effective. It is essential to ensure all protected and conserved areas are effective and to realise that paper parks, degazetting and poorly resourced protected and conserved areas are a major problem for the CBD and for global conservation. There is little point in establishing these places unless they are effective in the long term.

\section{THE CHALLENGE AND OPPORTUNITY OF OTHER EFFECTIVE AREA-BASED CONSERVATION MEASURES}

The 'at least 30 per cent' by 2030 target includes other effective area-based conservation measures (OECMs), first referenced by CBD Aichi Target 11 with a definition and criteria adopted by Parties at COP14 (Convention on Biological Diversity, 2018). To date, there have been few OECMs reported to Protected Planet, but many countries are considering OECMs to achieve 30 per cent. This is both a challenge and an opportunity. OECMs should not displace efforts to create additional protected areas or be considered as some lesser form of conservation. Under the CBD decisions, OECMs are meant to complement protected areas and should be equally important for maintaining biodiversity. They must demonstrate that they are delivering effective long -term conservation of important biodiversity. Although OECMs may not be managed primarily for conservation, they should achieve the same level of insitu, or whole ecosystem, biodiversity conservation as protected areas. Multiple-use production areas (e.g., production forests, plantations and industrial fisheries areas) that are managed with some biodiversity considerations should not be promoted as OECMs. While such areas are important, they should be counted towards additional sustainable use targets and not towards the 30 per cent conservation target. It is critical that we get the recognition, reporting and support of OECMs right. They may be especially useful for assisting Indigenous Peoples and Local Communities to achieve their conservation objectives and provide recognition and support for their work. However, they must not be seen as a lesser path to achieve 30 per cent by 2030 . IUCN has provided detailed guidance on OECMs (IUCN -WCPA, 2019) that is consistent with the CBD decision and is developing a range of decision support tools.

\section{THE PATH FORWARD}

The 'at least 30 per cent' by 2030 target for area-based conservation will contribute to a range of targets in the Global Biodiversity Framework, as well as other multilateral environmental agreements. In addition to conserving nature, increased area-based conservation provides many additional benefits, contributing to food and water security, healthy communities, livelihoods, and climate change adaptation and mitigation, among others. Well managed protected areas will also reduce the likelihood of the emergence of new zoonotic diseases. The momentum on area-based conservation over the last decade provides encouragement to Parties to the CBD to continue their efforts for more ambitious conservation targets for the Post-2020 Global Biodiversity Framework and strengthens hope for the United Nations' 2030 Agenda for Sustainable Development.

We call on Parties to the CBD, international organisations, development partners, management agencies and civil society to speak a common language when implementing a global goal of protecting at least 30 per cent by 2030. This is an enormous opportunity for conservation, for halting biodiversity loss, and responding to the climate crisis. Well managed protected and conserved areas are an essential part of solving the global biodiversity crisis, while protecting carbon stocks in nature helps to address the climate crisis. Let us focus on quality and equity, and ensure our systems of protected and conserved areas deliver strong conservation outcomes. Nature is in crisis. We must step up and act.

\section{ENDNOTES}

IUCN (2021). The Marseille Manifesto. IUCN World Conservation Congress, Marseille, France. https:// www.iucncongress2020.org/programme/marseille-manifesto. iiThe High Ambition Coalition for Nature and People (2021). https://www.hacfornatureandpeople.org/ 


\section{ABOUT THE AUTHORS}

Stephen Woodley is an ecologist, who has worked in environmental conservation as a consultant, a field biologist, researcher, and first Chief Scientist for Parks Canada. He is Vice Chair for Science and Biodiversity of IUCN's World Commission on Protected Areas, focusing on the role of protected areas as solutions to the current global conservation challenges.

Madhu Rao is the elected Chair of IUCN's World Commission on Protected Areas. She is also Senior Advisor for WCS and serves as Strategic Advisor for the IUCN SSC convened Asian Species Action Partnership. Madhu has engaged with international conservation policy platforms such as CITES and CBD and has published in the peer-reviewed literature on topics related to protected area policy and threatened species conservation to human wildlife conflict, conservation prioritization and governance. Her core strength at the science-policy interface is complemented by practical, field implementation experience across Asia and the ASEAN region with protected area creation, management and policy.

Kathy MacKinnon is the former Chair of IUCN's World Commission on Protected Areas. She has spent a lifetime working on protected and conserved areas, from early fieldwork in Southeast Asia to serving as the Lead Biodiversity Specialist at the World Bank. She cochairs the WCPA Specialist Group on other effective area-based conservation measures (OECMs). Dr. Mackinnon received the MIDORI prize in 2018.

Trevor Sandwith is a South African ecologist and nature conservation strategist who promotes the integration of protected and conserved areas in sustainable economic and social development. He has experience in the governance and management of protected and conserved area systems, and in mainstreaming biodiversity considerations into development policies and planning. At international level, he has specialized in transboundary governance of protected areas and in seeking recognition of ecosystem -based approaches to address climate change. He is Director of IUCN's Centre for Conservation Action.

Nigel Dudley is a consultant ecologist and partner at Equilibrium Research who works across many areas of conservation, planning and management.

\section{REFERENCES}

Convention on Biological Diversity (2018). CBD Decision 14/8: Protected areas and other effective area-based conservation measures. Conference of the Parties 14th meeting, Sharm El-
Sheikh, Egypt, 17-29 November. https://www.cbd.int/doc/ decisions/cop-14/cop-14-dec-08-en.pdf.

Hilty, J., Worboys, G.L., Keeley, A., Woodley, S., Lausche, B., Locke, H., Carr, M., Pulsford I., Pittock, J., White, J.W., Theobald, D.M., Levine, J., Reuling, M., Watson, J.E.M., Ament, R. and Tabor, G.M. (2020). Guidelines for conserving connectivity through ecological networks and corridors. Best Practice Protected Area Guidelines Series No. 30. Gland, Switzerland: IUCN. http://dx.doi.org/10.2305/ IUCN.CH.2020.PAG.30.en

Hockings, M., Hardcastle, J., Woodley, S., Sandwith, T., Wilson, J., Bammert, M., Valenzuela, S., Chataigner, B., Lefebvre, T., Leverington, F., Lopoukhine, N., MacKinnon, K. and Londoño, J.M. (2019). The IUCN Green List of Protected and Conserved Areas: Setting the standard for effective areabased conservation. PARKS 25(2): 57-66. https:// doi.org/10.2305/IUCN.CH.2019.PARKS-25-2MH.en

IUCN (2016). A Global Standard for the Identification of Key Biodiversity Areas, Version 1.0. First edition. Gland, Switzerland: IUCN. ISBN 978-2-8317-1835-4

IUCN-WCPA Task Force on OECMs (2019). Recognising and reporting other effective area-based conservation measures. Gland, Switzerland: IUCN. http://dx.doi.org/10.2305/ IUCN.CH.2019.PATRS.3.en

IUCN-World Commission on Protected Areas (2021). Conserving at least $30 \%$ of the planet by 2030: What should count? https://www.iucn.org/commissions/world-commissionprotected-areas/resources

Naidoo, R., Gerkey, D., Hole, D., Pfaff, A., Ellis, A.M., Golden, C.D., Herrera, D., Johnson, K., Mulligan, M., Ricketts, H. and Fisher, B. (2019). Evaluating the impacts of protected areas on human well-being across the developing world. Science Advances 5(4): eaav3006. https://doi.org/10.1126/ sciadv.aav3006

Schuster, R., Germain, R.R., Bennett, J.R., Reo, N.J. and Arcese, P. (2019). Vertebrate biodiversity on Indigenous managed lands in Australia, Brazil, and Canada equals that in protected areas. Environmental Science and Policy 101: 1-6. https:// doi.org/10.1016/j.envsci.2019.07.002

Tauli-Corpuz, V., Alcorn, J., Molnar, A., Healy, C. and Barrow, E. (2020). Cornered by PAs: Adopting rights-based approaches to enable cost-effective conservation and climate action. World Development 130: 104923. https://doi.org/10.1016/ j.worlddev.2020.104923

UNEP-WCMC, IUCN (2021). Protected Planet: The World Database on Protected Areas (WDPA). https:// www.protectedplanet.net/en.

Woodley, S., Locke, H., Laffoley, D., MacKinnon, K., Sandwith, T. and Smart, J. (2019). A review of evidence for area-based conservation targets for the Post-2020 Global Biodiversity Framework. PARKS 25(2): 19-30. https://doi.org/10.2305/ IUCN.CH.2019.PARKS-25-2SW2.en 


\section{RESUMEN}

El aumento de la conservación basada en áreas es primordial para detener la pérdida de biodiversidad y hacer frente al cambio climático. Las partes del Convenio sobre la Diversidad Biológica están dispuestas a adoptar el objetivo de proteger al menos el 30\% de las tierras, los mares y el agua dulce de la Tierra para 2030. Esto está enmarcado en el borrador del Marco Global de Biodiversidad y es apoyado por más de 70 países que se han unido a la Coalición de Alta Ambición. La Comisión Mundial de Áreas Protegidas de la UICN, en colaboración con el Centro Mundial de Monitoreo de la Conservación del PNUMA, National Geographic, la Sociedad para la Conservación de la Vida Silvestre y Birdlife International, ha publicado las directrices "Conservar al menos el 30\% del planeta para 2030: ¿qué se debería considerar?" Estas directrices exigen atención especial a la calidad como elemento esencial de los objetivos de conservación basados en áreas de gran tamaño. La calidad incluye muchos elementos, entre ellos el establecimiento de áreas protegidas y conservadas en zonas importantes para la biodiversidad, la forma en que están diseñadas y conectadas ecológicamente, además de asegurar la eficacia de la gestión y la equidad de la gobernanza. Pero las áreas protegidas y conservadas se deben promover en plena colaboración con las comunidades indígenas y locales. El objetivo mínimo del 30\% representa una importante oportunidad para reforzar los derechos de tenencia de la tierra, la seguridad de la tenencia y el acceso a la tierra, especialmente para los pueblos indígenas, y para apoyar los esfuerzos de conservación dirigidos por los pueblos indígenas y las comunidades locales (IPLC, por sus siglas en inglés). El avance hacia la protección de al menos el 30\% de la Tierra para 2030 es un gran reto en el que debemos hablar con una sola voz.

\section{RÉSUMÉ}

L'augmentation de la conservation par zone est essentielle pour stopper la perte de biodiversité et répondre au changement climatique. Les parties présentes à la Convention sur la diversité biologique sont sur le point d'adopter un objectif de protection englobant au moins 30 pour cent des terres, des mers et de l'eau douce de la Terre d'ici 2030. Cet objectif fait parti du projet initial du cadre mondial de la biodiversité soutenu par plus de 70 pays qui ont rejoint la Coalition de la Haute Ambition. La Commission mondiale des aires protégées de l'UICN, en partenariat avec le Centre mondial de surveillance de la conservation du PNUE, le National Geographic, la Wildlife Conservation Society et Birdlife International, a publié des directives intitulées « Le monde doit protéger 30 \% des terres et des océans d'ici 2030. Est-ce réalisable ?». Ces orientations appellent à mettre l'accent sur la qualité en tant qu'élément essentiel des objectifs de conservation par zone à grande échelle. La qualité comprend de nombreux éléments, notamment l'établissement d'aires protégées et conservées dans des zones importantes pour la biodiversité, la manière dont elles sont conçues et écologiquement connectées, et l'efficacité de la gestion et de l'équité de la gouvernance. Mais les aires protégées et conservées doivent être réalisées en partenariat absolu avec les communautés autochtones et locales. L'objectif minimum de $30 \%$ offre une opportunité importante de renforcer les droits à la terre, les droits fonciers et d'utilisation en particulier pour les peuples autochtones, et le soutien aux efforts de conservation menés par les PACL. Protéger au moins 30 \% de la terre d'ici 2030 est un grand défi pour lequel nous devons tous parler un langage commun. 